\title{
The Consequence of Partner Relationship Quality to Predict the Successful Performance of Small and Medium Enterprises (SMEs) International Joint Ventures (IJVs) in Thailand Industrial Sectors
}

\author{
Wanida Wadeecharoen \\ Faculty of Business Administration \\ Thonburi University \\ Bangkok, Thailand \\ Athiwat Kanjanavanikul \\ Faculty of Business Administration \\ Thonburi University \\ Bangkok, Thailand \\ Sombat Teekasap \\ Faculty of Engineering \\ Eastern Asia University \\ Bangkok, Thailand
}

\begin{abstract}
Purpose:This study highlighted the important of partner relationship quality captured by bonding, empathy, reciprocity and trust in SME IJV firms. Despite, there has been no systematic analysis has found in the literature regarding to partnership quality in term of relationship marketing (RM) and its effect on IJV business performance across several Thailand's industrial sectors..

Methodology/Sampling: By systematic random sampling, 835 questionnaires were distributed and $341(42 \%)$ usable cases were returned for the final analysis. The study examines the direct and indirect effect of partner relationship quality and its consequence on SME IJV in Thailand across several industrial sectors.

Findings: The results of the study confirmed the significant important of partner relationship quality represented by bonding, empathy, reciprocity and trust have fully mediated the relationship between MO and SME IJV performance.

Practical Implications: Based on this finding, partner relationship quality is implicit to be important predictors to determine the successful of SME IJV in Thailand.
\end{abstract}

Keywords: SME, IJV, Relationship Quality, Thailand.

JEL Classification: F23, M13.

* The material presented by the authors does not necessarily portray the viewpoint of the editors and the management of the Institute of Business \& Technology (IBT).

* Wanida Wadeecharoen: wadeecharoen@gmail.com

* Athiwat Kanjanavanikul

* Sombat Teekasap

C JMSS is published by the Institute of Business and Technology (IBT). Main Ibrahim Hydri Road, Korangi Creek, Karachi-75190, Pakistan. 


\section{INTRODUCTION}

Small and medium business enterprises (SMEs) have become globalization of business unit recognized by World Trade Organization (WTO), United Nation (UN), European Union (EU) and so on. In ASEAN Economic Community (AEC), SME has become an engine booth up for economic growth, distributes economic wealth to national remote region, reduces income gaps and enhances economic resiliency (Ngammaneeudom, 2012). Since, SMEs in Thailand currently reached to 2.9 million projects across all business sectors. This is generated of national employment for 9.7 million people or accounts about 80 percent of all national jobs (Public Relations Department: 18 March 2013). Particularly, SMEs in Thailand manufacturing sectors are represented by international joint venture (IJV) firms; or 34 percent of manufacturing projects are engaged in SME IJV (Wadeecharoen \& Nik Mat, 2010). Accordingly, IJV becomes a popularity strategic mode used by foreign firms to enter Thailand (Kajanavanikul, Wadeecharoen \&Teekasap, 2011; Julion \& O'Cass, 2005). This SME IJV trend enhanced the number of projects to 762 in 2010, an increasing of 200 projects or 26 percent from year 2009 and stayed steady to 793 in 2011 . Despite this, in the half of year 2012 (Jan-June) the number of SME IJV had reached to 470 projects or caught up to 60 percent as compared to whole year in 2011(refers to table 1). This is a vital evident to support the good sign of Thailand economic position still in a good health and getting fast recovered from flooding crisis in last quarter of 2001 (Wadeecharoen, Kanjanavanikul, Lertnaisat\&Teekasap, 2012a:c).

Table 1

Foreign Investment through BOI Classified by Mode of Internationalization

\begin{tabular}{|c|c|c|c|c|c|c|c|c|c|c|c|c|}
\hline \multirow{2}{*}{$\begin{array}{l}\text { Investment } \\
\text { Size }\end{array}$} & \multicolumn{2}{|l|}{2007} & \multicolumn{2}{|l|}{2008} & \multicolumn{2}{|l|}{2009} & \multicolumn{2}{|l|}{2010} & \multicolumn{2}{|c|}{2011} & \multicolumn{2}{|c|}{$\begin{array}{l}2012 \\
\text { (Jan-June) }\end{array}$} \\
\hline & No. & $\begin{array}{l}\text { Million } \\
\text { Baht }\end{array}$ & No. & $\begin{array}{l}\text { Million } \\
\text { Baht }\end{array}$ & No. & $\begin{array}{l}\text { Million } \\
\text { Baht }\end{array}$ & No. & $\begin{array}{l}\text { Million } \\
\text { Baht }\end{array}$ & No. & $\begin{array}{l}\text { Million } \\
\text { Baht }\end{array}$ & No. & $\begin{array}{l}\text { Million } \\
\text { Baht }\end{array}$ \\
\hline${ }^{1}$ Total IJV & 357 & 267,608 & 342 & $\begin{array}{l}191,37 \\
1\end{array}$ & 253 & 54,341 & 298 & 95,684 & 296 & $\begin{array}{l}108,62 \\
5\end{array}$ & 182 & 70,979 \\
\hline Total FDI & 836 & 505,612 & 838 & $\begin{array}{l}351,14 \\
2\end{array}$ & 614 & $\begin{array}{l}142,07 \\
7\end{array}$ & 856 & 279,233 & 904 & $\begin{array}{l}278,44 \\
7\end{array}$ & 541 & $\begin{array}{l}171,09 \\
2\end{array}$ \\
\hline $\begin{array}{l}\text { \% of IJV/ } \\
\text { Total FDI }\end{array}$ & $57 \%$ & $\begin{array}{l}238,004 \\
(47 \%)\end{array}$ & $61 \%$ & $\begin{array}{l}159,77 \\
1 \\
(45 \%)\end{array}$ & $42 \%$ & $\begin{array}{l}87,736 \\
(39 \%)\end{array}$ & $35 \%$ & $\begin{array}{l}183,549 \\
(34 \%)\end{array}$ & $\begin{array}{l}33 \\
\%\end{array}$ & $\begin{array}{l}169,82 \\
2 \\
(39 \%)\end{array}$ & $\begin{array}{l}34 \\
\%\end{array}$ & $\begin{array}{l}100,11 \\
3 \\
41 \%\end{array}$ \\
\hline $\begin{array}{ll}{ }^{2} \text { SME } & \text { FDI } \\
<500 & \end{array}$ & 703 & 71,954 & 744 & 72,568 & 562 & 45,979 & 762 & 71,931 & 793 & 73,163 & 470 & 48,214 \\
\hline $\begin{array}{l}(1-2) \% \text { of } \\
\text { SME IJV }\end{array}$ & $50 \%$ & $\begin{array}{l}195,654 \\
(27 \%)\end{array}$ & $46 \%$ & $\begin{array}{l}118,80 \\
3 \\
(38 \%)\end{array}$ & $63 \%$ & $\begin{array}{l}(8,362) \\
15 \%\end{array}$ & $40 \%$ & $\begin{array}{l}23,753 \\
(75 \%)\end{array}$ & $\begin{array}{l}37 \\
\%\end{array}$ & $\begin{array}{l}35,462 \\
(33 \%)\end{array}$ & $\begin{array}{l}39 \\
\%\end{array}$ & $\begin{array}{l}22,765 \\
(32 \%)\end{array}$ \\
\hline
\end{tabular}

Source: Author's calculation based on data provided by Board of Investment (BOI) Thailand: 2012

The largest of SME IJVs are engaged in metal and machinery following by electric and electronic sector while the second largest are engaged in chemicals and paper sector. In 2011 , the 300 of foreign investment projects were engaged in metal and machinery with worth 86,158 million baht followed up by 180 projects from electric and electronic sector worthy 61,196 million baht and 101 projects in chemicals worthy 37,960 million baht (refers to table 2). Over looked into electric and electronic sector, the investment value was 61,194 million baht, a decrease of 44,922 million baht or 42 percent decline as compared to year 2010. The phenomenon cause by the impact of floods on industrial productivity, particularly in hard disk drives and electric appliances production (MCOT: 6 Jan 2012). Despite 
this, in the first half of year 2012 after the flooding disaster returned to normal situation, Thailand foreign investment project has rebounded sharply as well as most of industrial factories boosts up their productivity rapidly from 2011 year's floods (BBC: News Business; 21 May 2012). In Jan to June 2012, the investment projects rose up to 692 worthy 278,470 million baht, the value investment in the first half of year 2012 was equal to whole year 2011. This phenomenon can clarify by critical rationale of Thailand competitive advantage in term of cheap labor and available of resources to respond of domestic consumption and for export orientation. Based on this view, Thai's government has been promoting SME plan in term of enhance Thai's SME knowledge-based and organization dynamics. Thus, IJV is the right alternative used for acquiring core-knowledge from foreign partner such as technology transfers, marketing knowledge to keep moving into quality ladder (Mohamad, Ramayah \& Hathaivaseawong, 2010).

Table 2

Foreign Investment Projects Approved by BOI classified by Sector

\begin{tabular}{|c|c|c|c|c|c|c|c|c|c|c|c|c|}
\hline \multirow[t]{2}{*}{ Sector } & \multicolumn{2}{|c|}{2007} & \multicolumn{2}{|c|}{2008} & \multicolumn{2}{|c|}{2009} & \multicolumn{2}{|c|}{2010} & \multicolumn{2}{|c|}{2011} & \multicolumn{2}{|c|}{$\begin{array}{l}2012 \\
\text { (Jan-June) }\end{array}$} \\
\hline & No. & $\begin{array}{l}\text { Million } \\
\text { Baht }\end{array}$ & No. & $\begin{array}{l}\text { Million } \\
\text { Baht }\end{array}$ & No. & $\begin{array}{l}\text { Million } \\
\text { Baht }\end{array}$ & No. & $\begin{array}{l}\text { Million } \\
\text { Baht }\end{array}$ & No. & $\begin{array}{l}\text { Million } \\
\text { Baht }\end{array}$ & No. & $\begin{array}{l}\text { Million } \\
\text { Baht }\end{array}$ \\
\hline Agriculture & 43 & 23,415 & 54 & 9,674 & 60 & 16,171 & 72 & 17,534 & 62 & 18,361 & 38 & 1717,754 \\
\hline Mineral\& & 28 & 32,379 & 33 & 25,071 & 13 & 3,284 & 18 & 33,449 & 31 & 24,961 & 16 & 7,677 \\
\hline Ceramics & 58 & 9,442 & 67 & 10,371 & 48 & 5,612 & 65 & 9,324 & 62 & 11,501 & 37 & 15,463 \\
\hline Light Industrial & 212 & 122,020 & 220 & 87,141 & 157 & 44,424 & 217 & 49,258 & 300 & 86,158 & 240 & 108,881 \\
\hline $\begin{array}{ll}\text { Metal } & \text { \& }\end{array}$ & 175 & 100,300 & 141 & 60,133 & 108 & 37,624 & 189 & 106,118 & 180 & 61,196 & 134 & 59,657 \\
\hline Electric & 114 & 96,451 & 117 & 41,737 & 63 & 15,438 & 107 & 19,114 & 101 & 37,960 & 97 & 27,331 \\
\hline $\begin{array}{l}\text { Electronic } \\
\text { Chemicals \& } \\
\text { Paper Services }\end{array}$ & 206 & 121,606 & 206 & 117,015 & 165 & 19,525 & 188 & 44,435 & 166 & 38,309 & 130 & 41,704 \\
\hline Total & 751 & 266,644 & 836 & 505,612 & 838 & 351,142 & 614 & 142,077 & 904 & 278,447 & 692 & 278,470 \\
\hline
\end{tabular}

Source: Author's calculation based on data provided by Board of Investment (BOI) Thailand: 2012

Despite this, IJV partners in term of information and technology interaction, such foreign partners are welcome to share their advance knowledge with their local partner is still diversity and inconclusive (Wadeecharoen, Kanjanavanikul, Pattana, \&Sombat, 2012:b). As this point becomes critical issue of IJV disputation with finally ending with IJV dissolution (Millington \&Bayliss, 1999). There are numerous lessons that explore the high failure rate of IJV ranging between 30 to 70 percent in several countries (Makino, Shige, Beamish \& Zhao, 2004; Yeheskel, Newburry\&Zeira, 2004; Hennart, Kim \& Zeng, 1998) and particularly IJV in Thailand has failure as high as 25 percent (Wadeecharoen et al., 2012:b; Wadeecharoen \& Nik Mat, 2010a:b; 2009).

Consequently, this study is over-emphasizing inter-partner relationship problem causing high failure rate of IJVs (Robson, Leonidou \& Katsikeas, 2002). Despite this, the effect of relational factors on successful SME IJV performance is fragmented and unpredictable (Wadeecharoen\&Nik Mat, 2011: 2010a:b; Thuy \& Quang, 2005; Demirbag \& Mirza, 2000). Hence, this is the first study grouping the relationship marketing variable represented by bonding, empathy, reciprocity and trust into concept of partnership quality and testing each variable individually. The concept of partner relationship quality is adapted from Yau, McFetridge, Chow, Lee, Sin \&Tse, (2000). In doing so, the purpose of this study 
attempts to represent an innovation concept of partner relationship quality and its consequence effect on SME IJV in Thailand industrial sectors. The variable to define the concept of partner relationship quality is adapted from relationship marketing variable which has not been tested individually before in IJV setting. Both direct and indirect effects are included in the research model and tested empirically.

\section{LITERATURE REVIEW}

Clarifying the definition of partners relationship quality 'what it is?' and 'how it works?' in inter-organization is the initial stage to interpreting the clear picture of joint venture partnership in small and medium enterprise (SME) international joint venture (IJV) organization. Following by the definition of SME IJV and its performance measurement which will be discussing in the following section below.

\subsection{Definition of Partner Relationship Quality}

The definition of partner relationship quality is still fragmented and limited in the literature. Among them two definitions are as follows:

'Relationship quality in inter-firm power was operationalized as satisfaction, cooperation and relationship stability'.

Johnson, Sakano, Cote \& Onzo, (1993)

'The inter-firm relationship (IFRs) effectiveness was conceptualize as the presence of norm of reciprocity, quality of information exchange and the degree of cooperative between the firms'.

Johnson \& Sohi, (2001)

Based on the definition of Johnson, Sakano, Cote \& Onzo, (1993) and Johnson \&Sohi, (2001) have given the similarity concept of partner relationship quality as far as, these relationship concepts were originated from relational theory (Macualay, 1963). Thus, this study will be developed a rich picture of inter-partner interactions and responses to bonding, empathy, reciprocity and trust (Yau, MaFetridge, Chow \& Lee, 2000).

\subsection{Definition of SME and IJV Organization}

The several definition of small and medium enterprises or SMEs were diversified into difference concept depend up on the countries. Noticeably, the concept of SME is originated up on the number of employees and fixed assets. Moreover, in USA annual receipt was used to define SME in some particular sectors such as general \& heavy construction, special trade contractor and agricultural industries (refers to table 3 ). 
The Consequence of Partner Relationship Quality to Predict the Successful Performance of Small and Medium Enterprises (SMEs) International Joint Ventures (IJVs) in Thailand Industrial Sectors

Table 3

The definitions of SME in Asian Pacific Economic Cooperation (APEC)

\begin{tabular}{|c|c|c|c|}
\hline Country & Sector & Employment & Other Measures \\
\hline \multirow[t]{2}{*}{ Australia } & Manufacturing & Less than 100 employees & \\
\hline & Service & Less than 20 employees & \\
\hline \multirow[t]{2}{*}{ Canada } & Manufacturing & Less than 500 employees & \\
\hline & Service & Less than 50 employees & \\
\hline China & $\begin{array}{ll}\text { Varies } & \text { with } \\
\text { Industry } & \end{array}$ & Usually less than 100 employees & \\
\hline Indonesia & & Less than 100 employees & \\
\hline \multirow{3}{*}{ Japan* } & Manufacturing & Less than 300 employees & $¥ 300$ million assets \\
\hline & Wholesaling & Less than 100 employees & $¥ 100$ million assets \\
\hline & Retailing-Service & Less than 50 employees & $¥ 100$ million assets \\
\hline \multirow[t]{2}{*}{ Korea } & Manufacturing & Less than 300 employees & \\
\hline & Service & Less than 20 employees & \\
\hline Malaysia & Varies (for SMI) & $\begin{array}{l}\text { Less than } 75 \text { employees } \\
\text { (Different for Bumiputra } \\
\text { Enterprises) }\end{array}$ & Less than RM 2.5 million \\
\hline \multirow{4}{*}{ Thailand** } & Production & Less than 200 employees & Less than THB 200 million \\
\hline & Service & Less than 200 employees & Less than THB 200 million \\
\hline & Wholesale & Less than 50 employees & Less than THB 100 million \\
\hline & Retail & Less than 30 employees & Less than THB 60 million \\
\hline Philippines & & Less than 200 employees & P 40 million assets \\
\hline \multirow[t]{2}{*}{ Singapore } & Manufacturing & & $\begin{array}{l}\text { Less than } \$ 12 \text { million fixed } \\
\text { assets }\end{array}$ \\
\hline & Service & Less than 100 employees & \\
\hline \multirow{6}{*}{ USA*** } & Manufacturing & Less than 500 employees & \\
\hline & Wholesaling & Less than 100 employees & \\
\hline & Retailing-Service & & $\begin{array}{l}\$ 7 \text { million of annual receipts } \\
\text { for most retail and service } \\
\text { industries }\end{array}$ \\
\hline & $\begin{array}{l}\text { General \& heavy } \\
\text { construction }\end{array}$ & & $\begin{array}{l}\$ 33.5 \text { million of annual receipts } \\
\text { for most general \& heavy } \\
\text { construct industries }\end{array}$ \\
\hline & $\begin{array}{l}\text { Special trade } \\
\text { contractor }\end{array}$ & & $\begin{array}{l}\$ 14 \text { million of receipts for all } \\
\text { special trade contractors }\end{array}$ \\
\hline & $\begin{array}{l}\text { Agricultural } \\
\text { industries }\end{array}$ & & $\begin{array}{l}\$ 0.75 \text { million of receipts for } \\
\text { most Agricultural industries }\end{array}$ \\
\hline
\end{tabular}

Source: (Wadeecharoen, Kanjanavanikul, Lertnaisat\&Teekasap, 2012)

Based on the table 4, the definition of Thai SME is similarity to SME Bank who defined SME as an enterprise which has employee less than 200 and fixed capital less than 200 million baht, excluding land and properties (SME bank, 2008). Thus, the concept of Thai SME defined by SME Bank is universally recognized and adapted in this study.

International joint venture or IJV is the organization established upon cooperation between multinational enterprises (MNEs) and the local firms, rapidly broadening a new 
economic trend since the beginning of 1990 (Park, 2010). IJV partner collectively invests financial as well as non-financial resources to pursue their certain objectives (Schuler \& Tarique, 2005). Each partner has an equity position representative on the company's board of directors separately and each expected proportionate share of dividend as their compensation (Glaister, 1998). Thus, IJV is an entity organization consists with two or more partners from different countries combining property and their expertise to carry out a single business organization. Then both partners are jointing proprietary interest, jointing right of control and sharing risk profits or losses (Nasution \& Mavondom, 2008). These specific characters of IJV seem problematic and difficult to manage due to lack of uncertain management skills. Furthermore, the numbers of IJVs involved in small and middle enterprises were not reported in the literature. Rather, only major ventures which involve relatively middle and large size were reported in company's directory. This rational is similarly supported by (Glaister\& Buckley, 1994; Hergert \& Morris, 1988).

As of the limitation of SME IJV conceptual operation and its definition as discussion above, this study has adopted the concept of SME IJV from Wadeecharoen, Kanjanavanikul, Lertnaisat \& Teekasap, (2012:a) who gave the most appropriate definition of SME IJV in Thailand as cited in the citation below;

"Small and Medium Enterprise (SMEs) International Joint Venture (IJV) is refers to IJV project with required minimum 10 percent of foreign capital and totals investment size is less than 500 million Baht”

(Wadeecharoen et al., 2012:a)

\subsection{Is Partner Relationship Quality for SME IJV Successful Performance?}

The reasons for IJV formulation need to be explored in order to answer the question, 'Does SME IJV need partnership quality? The holistic review of IJV formulation could be expanded into three reasons for instance (1) efficiency composed of cost reduction, utilized resources effectively, reduced risks or overcome governmental restrictions; (2) competition composed of enhancing market power or reduced competition; (3) learning composed of gaining a partner's know-how or resources (Banai \& Akande, 2005). Based on these reasons behind IJV motivation can contribute to firm competitive advantage over other modes of internationalization. This is because IJV opens the opportunity for MNEs or foreign firms to push out their resources and generate organization synergy. Additionally, the IJV goals congruity and the similarity of IJV motive become significant factors to determine successful IJV performance (Boateng \& Glaister, 2002). Thus, making a right partner is the initial stage of successful IJV. The partners who have similar goals seem to succeed. This is because both partners will contribute their resources to complementary motives for IJV achieving its goals. The possible approach to make this logic comes true is creating or generating IJV partner's relationship quality. Such relationship quality is concerned with inter-firm satisfaction, cooperation and relationship stability (Johnson et al., 1993); reciprocity, information exchange quality, partner's cooperative (Johnson \&Sohi, 2001); bonding, empathy, reciprocity and trust (Wadeecharoen, Kajanavanikul \& Teekasap, 2011; Wadeecharoen \& Nik Mat, 2009:2008; Yau et al., 2000). With these entire relational variables will contribute to partner relationship quality for making SME IJV successfully. 
The Consequence of Partner Relationship Quality to Predict the Successful Performance of Small and Medium Enterprises (SMEs) International Joint Ventures (IJVs) in Thailand Industrial Sectors

\subsection{How to Managing IJV Partners in long-term relationship?}

The established IJV is embarked for specific objective which is differ for the local and foreign partners. Such foreign firms enter into host country to gain local resources like cheap labor and access to its domestic market. Conversely, the local firms engaged with foreign partners from developing counties are behind advance technology know-how, management knowledge and access to its financial resources (Akanda, Adetoun, Tserere, Adewuyi \& Akande, 2010). Despite this, there has been no managerial system on how to manage partner relationship and its effect on inter-firm business's performance.

Based on the literature, it is found that IJV target market overlapping and transferring of technology between IJV partners are the cause of inter-partner competition and finally lead to unsuccessful of joint venture experience (Klendauer \& Deller, 2009). As of this point, an increase or decrease in IJV competition is one of the important factors that determines possibility of success of the IJV.

\subsection{The Consequence Dimension of Partner Relationship Quality}

Zyl \& Helm (2007) has presented a comprehensive model that can capture the partner relationship quality by using MO and RMO concept. They explored links between entrepreneurial leadership, strategic orientation and performance of South Africa's small tourism companies with RMO as mediators (refers to figure 1).

Figure 1

Model of Partner Relationship Quality

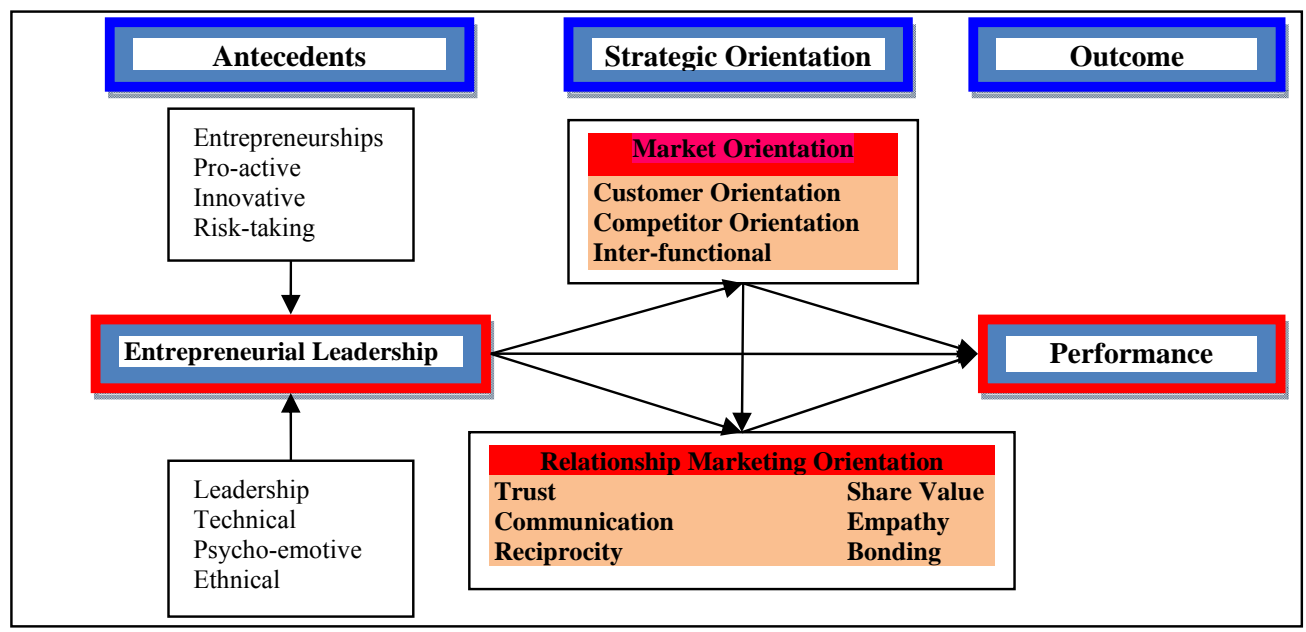

Source: Zyl\& Helm (2007)

Two year later, the study by Wadeecharoen \& Nik Mat, (2009) who adapted the concept of MO and RMO in the IJV partner relationship and their impact on IJV firms' performance. The result has shown a positive relationship impact between $\mathrm{MO}$ and IJV business performance $(\beta=.179 ; \mathrm{CR}=2.102 ; \mathrm{P}$-value $<0.036)$. RMO has a mediator effect between MO and IJV business performance ( $\beta$ indirect=.364> $\beta$ direct=.179) (refers to figure 2).

Figure 2 


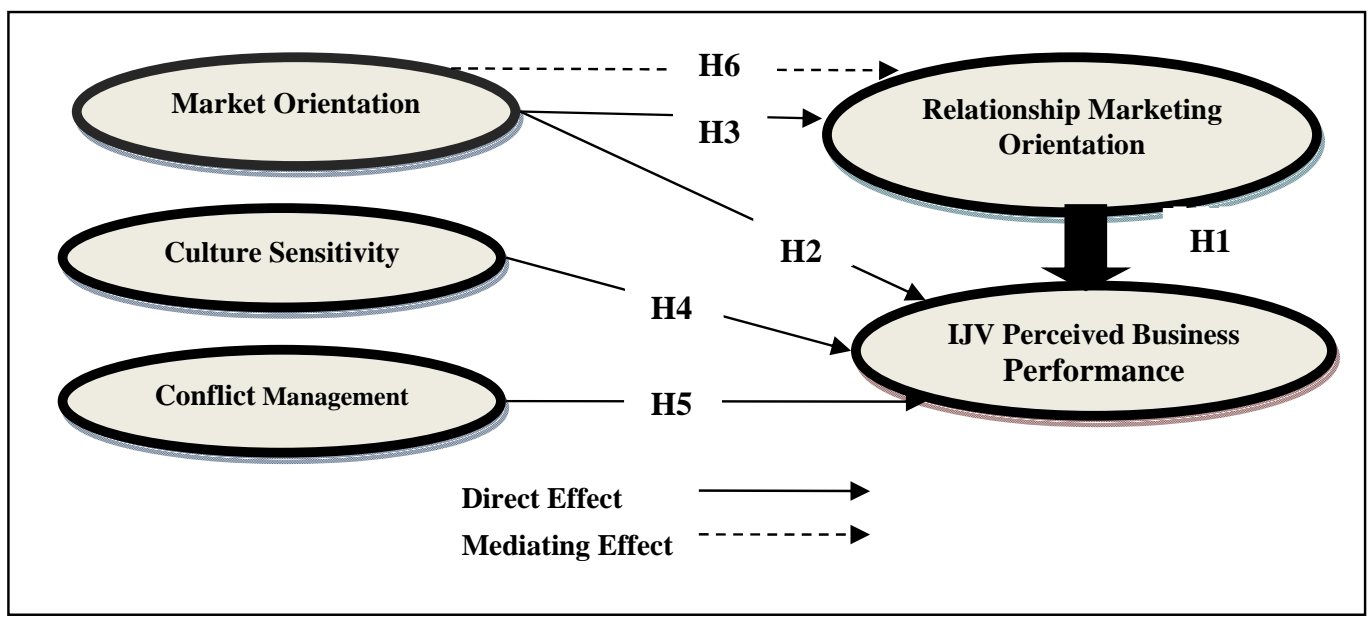

Source: Wadeecharoen\&Nik Mat, (2009)

Although relationship marketing (RM) was cited in simplistic research by using only a one-dimensional RM (Yau et al., 2000; Yau, 1995; Gronroos, 1990), the exact nature of RMO components in a single dimension such as bonding, empathy, reciprocity and trust and their effect on business performance has not been investigated earlier in IJV setting. To fulfill this research gap in the literature, this is the initial study to verify the concept of partner relationship quality by using RMO component in a single dimension and test their relationship effect on IJV business performance individually. Thus, the consequence dimension of partner relationship quality is representing in the research framework of the study as exhibited in the figure 3.

\section{RESEARCH FRAMEWORK OF STUDY}

The research framework of the study is highlights the partnership quality in Thailand SME IJV industrial sectors. The quality of partner relationship represented by RMO is an individual dimension namely bonding, empathy, reciprocity and trust (Yau at al., 2000). These relationship marketing variables are assumed to be having a significant positive impact on the success of SME IJV performance. Consequently, a research framework of this study is established in order to empirically test the linkage relationship in thirteen hypotheses as exhibited in the figure 3. 
The Consequence of Partner Relationship Quality to Predict the Successful Performance of Small and Medium Enterprises (SMEs) International Joint Ventures (IJVs) in Thailand Industrial Sectors

Figure 3

Theoretical Framework of Partner Relationship Quality

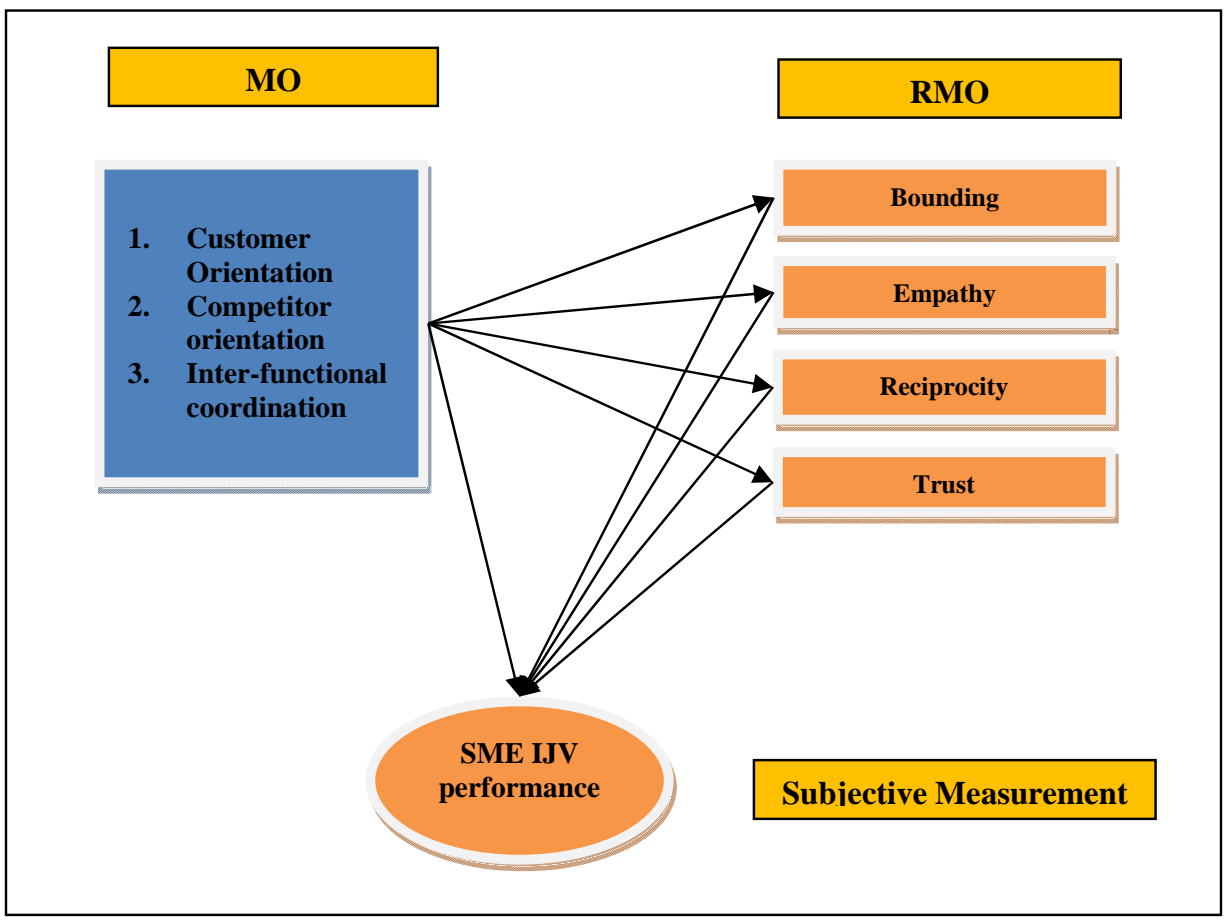

Table 5

Research Hypothesis

\begin{tabular}{|l|l|}
\hline \multicolumn{2}{|l|}{ Direct Relationship Effect } \\
\hline H1 & MO has positively effect on SME IJV performance. \\
H3 & MO has a positively effect on bounding. \\
H4 & MO has positively effect on empathy. \\
H5 & MO has a positively effect on reciprocity. \\
H6 & Bonding has positively effect on SME IJV performance. \\
H7 & Empathy has positively effect on SME IJV performance. \\
H8 & Reciprocity has positively effect on SME IJV performance. \\
H9 & Trust has positively effect on SME IJV performance. \\
\hline Indirect Relationship Effect \\
\hline H10 & Bonding has mediating effect on the relationship between MO and SME IJV performance \\
H11 & Empathy has mediating effect on the relationship between MO and SME IJV performance \\
H12 & Reciprocity has mediating effect on the relationship between MO and SME IJV performance. \\
H13 & Trust has mediating effect on the relationship between MO and SME IJV performance. \\
\hline
\end{tabular}




\section{METHODOLOGY}

\subsection{Research Sampling}

The sampling of SME IJV in this study was classified by size of operation based on the legal definition of SME IJV whereby the number of employees were less than 200 and foreign equity ownership of less than 50 percent (SME bank, 2008). The list of the local companies was attained from Thailand Company Information (2010-2011) and Factory Directory in Thailand (2011). By using systematic random sampling, a sample size of 835 SME IJVs firms was selected for the study. IJV managing directors (MD) or general managers (GM) who are the representative of SME IJV (either local or foreign partner) operating in Thailand was targeted as the key information person in this study. This is because he/she is the key person who knows about IJV management and is considered as information gatekeepers (Julian, 2010:2008; Julian \&O'Cass, 2005: 2004: 2002). Previous research provides a support for relying on the IJV general manager for reliable data (Geringer \& Hebert, 1991; Child, Yan \& Lu 1997).

\subsection{Instrument, Data Collection and Analysis Method}

Market orientation (MO) consists of three behavioral components: customer orientation, competitor orientation, inter-functional coordination, and two criteria decision: long-term focus and profitability. In this study, the measurement construct of MO was originally developed by (Narver \& Slater, 1990) and adapted into partner orientation where this instrument has been used by Farrell, Oczkowski, \& Kharabsheh, (2008) in IJV setting. The measurement or RMO construct is adapted from (Yau, et al., 2000). The SME IJV performance measurement is adopted from Cullen, John, Johnson, Jean, Sakino \& Tomoaki, (1995) and Thuy \& Quang, (2005).

Since MD or GM was identified as a respondent of the study. Questionnaire was distributed to MDs and GMs of 835 companies list by Thailand Company Information (20102011) and Factory Directory in Thailand (2011). However, 341 filled questionnaires returned constituting $42 \%$ of the total numbers sent. These 341 data cases were input into SPSS and analysis through AMOS to test a fix of research model and hypothesis respectively.

\section{RESULTS OF THE STUDY}

\subsection{Demography Profile of SME IJV in Thailand}

The research samples of the study are from 9 sub-industrial sectors and the largest sectors whereby SME IJVs are engaged into is manufacturing sector 33\%; second largest is heavy industrial $30.8 \%$; following by light industrial $14.4 \%$; food industry $7 \%$; construction $4.7 \%$; oil \& gas 3.2\%; agriculture industry $3.2 \%$; transportation $2.9 \%$ and telecommunication $.6 \%$ (see table 6). 
The Consequence of Partner Relationship Quality to Predict the Successful Performance of Small and Medium Enterprises (SMEs) International Joint Ventures (IJVs) in Thailand Industrial Sectors

Table 6

Industrial Sectors

\begin{tabular}{|c|c|c|}
\hline Industrial Sectors & Frequency & Percent \\
\hline . $\quad$ Oil \&Gas & 11 & 3.2 \\
\hline$\therefore \quad$ Light Industry & 49 & 14.4 \\
\hline i. Heavy Industry & 105 & 30.8 \\
\hline$\therefore \quad$ Manufacturing & 113 & 33.1 \\
\hline i. Food Industry & 24 & 7.0 \\
\hline i. Construction & 16 & 4.7 \\
\hline '. Agriculture Industry & 11 & 3.2 \\
\hline i. Transportation & 10 & 2.9 \\
\hline 1. Telecommunication & 2 & .6 \\
\hline Total & 341 & 100 \\
\hline
\end{tabular}

The majority partner is Japanese $45.8 \%$; follow up by Taiwanese $2.6 \%$; American $2 \%$; Singaporean 1.8; British 1.8\%; Swiss $1 \%$; Korea $1 \%$ and others consist of $0.3 \%$ each (Australian, Dutch, French ,Indian ,New Zealand) (see table 7). The majority of SME IJVs have been operating in Thailand more than 10 years.

Table 7

Multi-nationality of IJVs partner

\begin{tabular}{|c|c|c|}
\hline Respondents & Frequency & Percent \\
\hline 1. American & 7 & 2 \\
\hline 2. Australian & 1 & .3 \\
\hline 3. British & 6 & 1.8 \\
\hline 4. Dutch & 1 & .3 \\
\hline 5. French & 1 & .3 \\
\hline 6. Indian & 1 & .3 \\
\hline 7. Japanese & 156 & 45.8 \\
\hline 8. Korea & 3 & 1 \\
\hline 9. New Zealand & 1 & .3 \\
\hline 10. Singaporean & 6 & 1.8 \\
\hline 11. Swiss & 3 & 1 \\
\hline 12. Taiwanese & 9 & 2.6 \\
\hline 13. Thai & 146 & 42.8 \\
\hline Total & 341 & 100 \\
\hline
\end{tabular}

\subsection{Descriptive Analysis of Variables}

The research mode of this study combines with one exogenous and two endogenous variables. Each construct shows Cronbach alpha readings of acceptable values of above 0.8 , well above Nunnally, (1978) recommendation of 0.6 limits. 


\subsection{Goodness of Fit Results}

Table 8 shows the goodness fit indices for the empirical screening through confirmation factor analysis (CFA) of all factors included in this study. The overall CFAs of constructs (market orientation \& business performance) produced a relatively good fit as indicated by the goodness of fit indices such as CMIN/df ratio $(<2)$; p-value $(>0.05)$; Goodness of Fit Index (GFI) of $>.090$; and root mean square error of approximation (RMSEA) of value less than $0.08(<0.08)$ (Hair, Anderson, Tatham \& Black, 2006). Despite, TLI, NFI, AGFI, CFI of RMO CFA construct is below then .90 and p-value is below than 0.05 .

Table 8

Goodness of Fit Analysis-Confirmatory Factor Analysis (CFA) of Models (N=341)

\begin{tabular}{|l|l|l|l|l|l|l|l|l|l|l|l|}
\hline CFA Model & Items & CMIN & df & $\begin{array}{l}\text { p- } \\
\text { value }\end{array}$ & $\begin{array}{l}\text { CMIN/ } \\
\text { df }\end{array}$ & TLI & NFI & GFI & AGFI & CFI & Rmsea \\
\hline Market Orientation & 12 & 20.745 & 54 & 1.00 & .384 & 1.017 & .991 & 1.00 & .986 & 1 & .000 \\
\hline $\begin{array}{c}\text { RMO } \\
\text { 1. Bonding } \\
\begin{array}{l}\text { 2. Empathy } \\
\text { 3. Reciprocity } \\
\text { 4. Trust }\end{array}\end{array}$ & 12 & 224.967 & 50 & .000 & 4.499 & .777 & .796 & .907 & .854 & .831 & .101 \\
\hline Business Performance & 6 & 10.203 & 9 & .334 & 1.134 & .997 & .986 & .990 & .977 & .998 & .020 \\
\hline Hypothesis Model & 30 & 436.759 & 396 & .77 & 1.103 & .990 & .910 & .910 & .894 & .991 & .017 \\
\hline
\end{tabular}

\subsection{Hypothesis Testing}

This section discusses the hypotheses from two perspectives: direct and indirect impacts. The result of hypothesis model or structure equation model (SME) is exhibited in figure 5. The overall goodness of fit indices of hypothesis model is relatively good fit with achieved the required threshold levels using assessment criteria such as GFI, CFI, TLI, RMSEA (Bagozzi, Yi \& Nassan, 1998) (refers to table 9). The findings of direct and indirect effect are exhibited in table 9 and 10, respectively. 
The Consequence of Partner Relationship Quality to Predict the Successful Performance of Small and Medium Enterprises (SMEs) International Joint Ventures (IJVs) in Thailand Industrial Sectors

Figure 4

Hypothesis Model

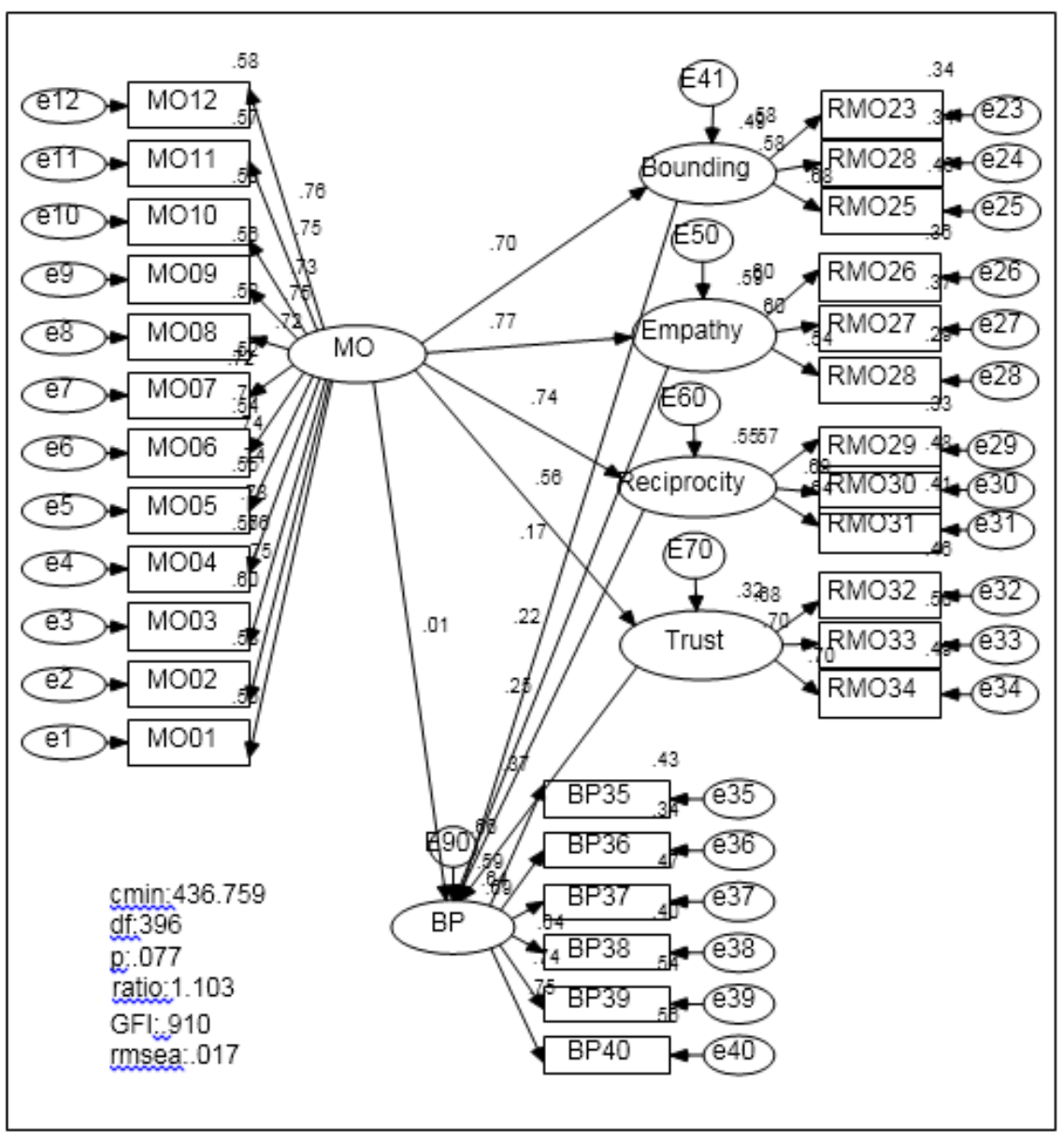

Table 9

Hypothesis Model (Goodness-Of-Fit indices)

\begin{tabular}{|l|l|l|}
\hline Measures & Fit Indices & Threshold Values \\
\hline Absolute Fit Level & & \\
RMSEA & .017 & Less than 0.08 \\
GFI & .910 & 0.9 and Above \\
P-Value & .77 & P-Value $\geq 0.05$ \\
\hline Increment Fit Level & & \\
AGFI & .897 & 0.90 and Above \\
CFI & .991 & 0.90 and Above \\
TLI & .990 & 0.90 and Above \\
NFI & .910 & 0.90 and Above \\
\hline Parsimonious Fit Level & & Less than 2.0 \\
CMIN/df & 1.103 & Bigger better \\
SMC $\left(\mathrm{R}^{2}\right)$ & .64 &
\end{tabular}




\subsubsection{The Direct Impact Hypothesis}

The result of the hypothesis model in table 9 and figure 4 (hypothesis model) demonstrates the relationship marketing orientation (RMO) in a single dimension consists with bonding, empathy, reciprocity and trust with SME IJV business performance. The results show a positive relationship between trust and SME IJV business performance $(\beta=.373 ; \mathrm{CR}=5.035$; $\mathrm{P}$-value $<0.001)$ thus $\mathrm{H} 9$ is asserted. Despite, bonding, empathy, reciprocity have no relationship effect on SME IJV business performance or H6; H7; H8 were not asserted respectively (see table 10).

Marketing orientation (MO) has insignificant positive impact on SME IJV business performance $(\beta=.012 ; \mathrm{CR}=.081)$ thus, $\mathrm{H} 5$ was not asserted. Likewise, marketing orientation has significant positive impact on RMO in each single dimension is as $\mathrm{MO}$ and bonding $(\beta=.699 ; \mathrm{CR}=.7904 ; \mathrm{P}$-value $<0.001) ; \mathrm{MO}$ and empathy $(\beta=.766 ; \mathrm{CR}=8.729 ; \mathrm{P}$-value $<0.001)$; $\mathrm{MO}$ and reciprocity $(\beta=.740 ; \mathrm{CR}=8.282 ; \mathrm{P}$-value $<0.001) ; \mathrm{MO}$ and trust $(\beta=.562 ; \mathrm{CR}=7.775$; $\mathrm{P}$-value $<0.001)$ thus, $\mathrm{H} 1 ; \mathrm{H} 2 ; \mathrm{H} 3$; H4 were asserted respectively. In summarize, hypotheses $\mathrm{H} 1 ; \mathrm{H} 2 ; \mathrm{H} 3$; H4 and $\mathrm{H} 9$ were asserted (significant Beta) while hypothesis H5; H6; H7; H8 were rejected (insignificant Beta).

The variance explaining by exogenous variables in the hypothesis model, firstly, MO explains $49 \%$ variance in bonding; $59 \%$ variance in empathy; $55 \%$ in reciprocity and $32 \%$ in trust respectively. Secondly, MO and RMO in single dimension such as bonding, empathy, reciprocity and trust explain $64 \%$ in SME IJV performance.

Table 10

Hypothesis Testing of Hypothesis Model (Direct Effect)

\begin{tabular}{|l|l|l|l|l|l|l|l|l|}
\hline H & \multicolumn{2}{|r|}{$\begin{array}{l}\text { Endogenous } \\
\text { Exogenous }\end{array}$} & $\begin{array}{l}\text { Std. } \\
\text { Estimat }\end{array}$ & S.E. & C.R. & P-value & Status \\
\hline H1 & Marketing Orientation & $\rightarrow$ & Bonding & .699 & .067 & 7.904 & $* * *$ & Sig. \\
\hline H2 & Marketing Orientation & $\rightarrow$ & Empathy & .766 & .066 & 8.729 & $* * *$ & Sig. \\
\hline H3 & Marketing Orientation & $\rightarrow$ & Reciprocity & .740 & .063 & 8.282 & $* * *$ & Sig. \\
\hline H4 & Marketing Orientation & $\rightarrow$ & Trust & .562 & .057 & 7.775 & $* * *$ & Sig. \\
\hline H5 & Marketing Orientation & $\rightarrow$ & SME IJV BP & .012 & .125 & .081 & .936 & Non-sig. \\
\hline H6 & Bonding & $\rightarrow$ & SME IJV BP & .169 & .099 & 1.894 & .058 & Non-sig. \\
\hline H7 & Empathy & $\rightarrow$ & SME IJV BP & .220 & .128 & 1.925 & .054 & Non-sig. \\
\hline H8 & Reciprocity & $\rightarrow$ & SME IJV BP & .253 & .117 & 2.560 & .010 & Non-sig. \\
\hline H9 & Trust & $\rightarrow$ & SME IJV BP & .373 & .079 & 5.035 & $* * *$ & Sig. \\
\hline
\end{tabular}

\subsubsection{The Indirect Impact Hypothesis}

Mediating Effect Analysis of Revised Model

Table 11 shows the indirect effect estimates to test mediating effects of RMO in a single dimension namely bonding, empathy, reciprocity and trust on market orientation and SME IJV business performance as hypothesized in hypotheses H10 to H13. Based on the result in table 11 bonding, empathy, reciprocity and trust have mediating effect on MO and 
The Consequence of Partner Relationship Quality to Predict the Successful Performance of Small and Medium Enterprises (SMEs) International Joint Ventures (IJVs) in Thailand Industrial Sectors

SME IJV business performance, hence asserted H10 ( $\beta$ indirect $=.119>\beta$ direct $=.012)$; H11 ( $\beta$ indirect $=.169>\beta$ direct $=.012) ; \mathrm{H} 12 \quad(\beta$ indirect $=.185>\beta$ direct $=.012)$ H13 $($ indirect $=.207>$ $\beta$ direct=.012) respectively.

Table 11

Hypothesis Testing of Hypothesis Model (Indirect and total Effect)

\begin{tabular}{|c|c|c|c|c|c|c|c|c|c|}
\hline & Exogenous & & Mediated & & Endogenous & $\begin{array}{c}\text { Indirect } \\
\text { Effects } \\
\text { (Std) } \\
\text { Estimate }\end{array}$ & $\begin{array}{l}\text { Direct Effect } \\
\text { (Std) }\end{array}$ & $\begin{array}{l}\text { Total } \\
\text { Effect }\end{array}$ & $\begin{array}{l}\text { Mediating } \\
\text { Hypothesis }\end{array}$ \\
\hline H10 & $\begin{array}{l}\text { Market } \\
\text { Orientation }\end{array}$ & $\rightarrow$ & Bonding & $\rightarrow$ & SME IJV BP & .119 & .012 & .131 & Mediating \\
\hline H11 & $\begin{array}{l}\text { Market } \\
\text { Orientation }\end{array}$ & $\rightarrow$ & Empathy & $\rightarrow$ & SME IJV BP & .169 & .012 & .181 & Mediating \\
\hline H12 & $\begin{array}{l}\text { Market } \\
\text { Orientation }\end{array}$ & $\rightarrow$ & Reciprocity & $\rightarrow$ & SME IJV BP & .185 & .012 & .197 & Mediating \\
\hline H13 & $\begin{array}{l}\text { Market } \\
\text { Orientation }\end{array}$ & $\rightarrow$ & Trust & $\rightarrow$ & SME IJV BP & .207 & .012 & .219 & Mediating \\
\hline
\end{tabular}

\section{DISCUSSION \& CONCLUSION}

The finding of the study was demonstrated the positive significant important of RMO in an individual constructs consists with bonding, empathy, reciprocity and trust (Yau et al., 2000). Based on the literature, the positive significant direct relationship between composite RMO and SME IJV performance is supported by various previous studies in non-IJV setting (Chattananon \& Trimetsoontorn, 2009; Gorden, Pires \& Stanton, 2008; Sin, Tse, Chan, Heung \&Yim, 2006; Sin, Tse, Yau, Chow \& Lee, 2005; Sharmeas, Katsikeas \& Schlegelmilich, 2002). Similarity, the positive impact of a single dimension RMO with business performance in IJV setting such as trust (Wilson \& Bernnan, 2009; Kwon, 2008; Lin \& Wang, 2008; Ng, Lau \&Nyam, 2007; Herbert, 1996), commitment (Julian \& O'Cass, 2008: 2004: 2002; Julian, 2003: 2005: 1998; Dermibag \& Mirza, 2000), and cooperation (Luo \& Park, 2004; Pearch, 2001; Tiessen \& Linton, 2000). Despite, composite RMO in IJV setting is still limited and fragmented. Only the study by Wadeecharoen \& Nik Mat, (2011: 2010: 2009) reveal the positive impact of composite RMO and IJV performance. However, an individual RMO dimension with business performance has not been testing before in the literature.

This study is the first innovator testing the relationship of individual RMO (bonding, empathy, reciprocity and trust) with SME IJV business performance. Surprisingly, there was no any relationship effect between bonding, empathy, reciprocity with IJV performance excepted trust. In other hand, bonding, empathy, reciprocity and trust have shown a mediator effect between MO and SME IJV performance while MO has no direct relationship impact on SME IJV performance. This finding implies SME IJV acquiring an excellent relationship marketing quality with partners in term of creating long lasting bonds, empathy, being reciprocal and having a high degree of trust among SME IJV partnering. When these RMO dimension exist in IJV partnership, both partners will be quickly wide responsiveness to customer needs (customer orientation) through inter-functional coordination across organization departments and they are able to outperform their competitor (competitor orientation) (Kohli \& Jaworski, 1990), this will be enhance SME IJV business performance respectively. Since MO has no relationship impact to SME IJV performance. Thus, to make 
this finding worthy, we recommend $\mathrm{MO}$ need to go to $\mathrm{RMO}$ in each individual dimension in order to increase SME IJV performance.

\section{REFERENCES}

Akande, W.A., Adetoun B.E., Tserere, M.M., Adewuyi, M.F., Akande, E.T. (2010). Should we put Locales in Charge? Managing Relationships within Prospective US-South African Joint Ventures. Journal of Business Economics and Management, 11(4):550-575

Bagozzi, R.P., Yi, Y., \& Nassen, K.D. (1998).Representation of Measurement Error in Marketing Variables: Review of Approaches and Extension to three-facet Designs. Journal of Econometrics, Vol.89,Issues 1-2.Nov 1998, Pages 398-421

Banai, M. \& Akande, A. (2005).South African Managers' Perception of a Joint Venture. JAB Col-laborative Monograph, 1.

BBC NEWS: BUSINESS: 'Thailand sees growth rebound after devastating floods' published 21/05/2012, retrieved on 7/06/12: http://www.bbc.co.uk/news/business

Boateng, A. \& Glaister, K.W. (2002).Performance of International Joint Ventures: Evidence for West Africa, International Business Review.11(5).

Chattananon, A., \& Trimetsoontorn, J. (2009).Relationship marketing a Thai case. International Journal of Emerging Markets.Vol.4, No.3.p.252-274

Child, J., Yan.,\& Lu, Y. (1997). Ownership and Control in Sino-Foreign Joint Ventures: San Francisco: The New Lexington Press.

Cullen, John, B., Johnson, Jean, L., Sakino, \& Tomoaki. (1995). Japanese and Local Partner Commitment to IJVs: Psychological Consequences of Outcome and Investments in the IJV Relationship. Journal of International Business Studies,26(1).

Demirbag\&Mirza, (2000).Factors affecting International Joint Venture success: an empirical analysis of foreign-local partner relationships and performance in Joint Venture in Turkey. International BusinessReview, 9:1-35.

Farrell, M.A., Oczkowski E., \& Kharabsheh, R. (2008).Market orientation, learning orientation and organizational performance in international joint ventures.Asia Pacific Journal of Marketing and Logistics, Vol.20, No.3, p. 289-308.

Farrell, M.A., Oczkowski E., \& Kharabsheh, R. (2008).Market orientation, learning orientation and organizational performance in international joint ventures. Asia Pacific Journal of Marketing and Logistics, Vol.20, No.3, p. 289-308.

Geringer, J.M., \& Hebert, L. (1991).Measuring Performance of International Joint Ventures. Journal of International Studies.22(2). 249.

Glaister, K. W, \& Buckley, P. J. (1998).Management-performance relationships in UK joint ventures. International Business Review 7, 235-257. 
Glaister, K.W., \& P.J.,Buckley.(1994). UK international joint ventures: An analysis of patterns of activity and distribution, British Journal of Management, 5(1)

Gordon T.L.O., Pires G.D., Stanton J. (2008) "The relationship marketing orientation of Hong-Kong financial services industry managers and its links to business performance" Journal of Financial Services Marketing, Vol.13, 3

Hair, F.J., Anderson, E.R., Tatham, L.R., \& Black, C.W. (1998).Multivariate Data Analysis Fifth Edition. New Jersey: Prentice-Hall

Hebert, L. (1996). Does control matter? A path model of the control-performance relationship in International Joint Ventures. Management International, Vol.1, No.1

Hennart, F., Kim D.J. \& Zeng, M. (1998). The Impact of Joint Venture Status on the Longevity of Japanese Stakes in U.S. Manufacturing Affiliates, Organization Science, 9(3), May-June ,382-395.

Hergert, M., \& Morris, D., Trends in International Collaborative Agreements, In F.J. Contractor and P. Lorange, eds. Co-operative Strategies in International Business, Lexington Books, Lexington, MA, 1998, 99-109

Johnson, J.L., Sakano, T., Cote, J.A., \& Onzo, N. (1993).The Exercise of Interfirm Power and Its Repercussions in U.S.-Japanese Channel Relationships. Journal of Marketing, Apr 1993; 57, 2; ABI.INFORM Global

Johnson, J.L., Sohi, R. S. (2001). The Influence of Firm Predisposition on Inter-firm Relationship Formation in Business Markets. International Journal of Research in Marketing 18 (2001) 299-318

Julian, C. C. (2005). International Joint Venture performance in South East Asia.MA: Edward Elgar.

Julian, C. C. (2010). The market orientation-marketing performance relationship - the empirical link in international joint ventures. International Journal of Trade and Global Markets, 3(4), 414-431.

Julian, C., \& O’Cass, A. (2002).The effect of firm and marketplace characteristics on International Joint Venture (IJV) marketing performance. Asia Pacific Journal of Marketing and Logistics, 14(1).

Julian, C., \& O'Cass, A. (2004). The impact of firm and environment characteristics on International Joint Venture (IJV) marketing performance in Thailand. Thunderbird International BusinessReview, 46 (4), 359-380.

Julian, C.C. (2008).Joint Venture Conflict: The Case of Thai International Joint Ventures", Journal of Asia-Pacific Business, 9(1).

Kanjanavanikul, A., Wadeecharoen, W., \&Teekasap, S. (2011).The Effect of Marketing Determinant towards Small and Medium Enterprise (SMEs) International Joint Venture (IJVs) Performance in Thailand Manufacturing Sectors. Proceeding of Asian Business \& Management Conference AMBC 2011. Sponsored by and publication by 
The International Academic Forum, iafor11-13 Nov, Ramada Osaka Hotel, Osaka, Japan

Klendauer, R., \& Deller, J. (2009). Organization Justice and Managerial Commitment in Corporate Mergers, Journal of Managerial Psychology 24(1): 29-45.

Kohli, A.K., \& Jaworski, B.J. (1990). Market Orientation: The Construct, Research Propositions and Management Implications. Journal of Marketing, forthcoming.

Kwon, Y.C., (2008). Antecedents and consequences of International Joint Venture partnerships: A social exchange perspective” International Business Review, 17:559573

Lin X., \& Wang C.L. (2008) "Enforcement and performance: The role ownership, legalism and trust in International Joint Venture" Journal of World Business 43, 340-351

Luo, Y., \& Park S.H. (2004). Multiparty cooperation and performance in international equity Joint Ventures. Journal of International Business Studies. Vol.35, No.2,p. 142-160.

Makino, Shige, Beamish P.W., \& Zhao, B. (2004). The characteristics and performance of JapaneseFDI in less developed and developed countries. Journal of World Business, 2004, vol. 39(4), 377-392.

MCOT News: 'Flood crisis effect on Thai economy highest in November: BOT': Published 6/01/12, retrieved on 6/06/12: http://www.pattayamail.com/business/

Millington A., \& Bayliss B. (1999).Transnational marketing joint ventures: A viable market penetration strategy in the E.U? European Management Journal, 17(6), 635-644

Mohamad, O., Ramayah, T., \& Hathaivaseawong.N. (2010). Transfer of marketing knowledge in Thai International Joint Venture Firms. Asian Academy of Management Journal, 15(2), 179-216.

Nasution, H.N., \& Mavondo,(2008). Organization capabilities: antecedents and implications for customer value, European Journal of Marketing 42(3-4): 477-501.

Naver, J.C., \& Slater, S.F. (1990). The effect of a market orientation on business profitability" Journal of Marketing, (October, 1990)

Ng, P.W., Lau C.M., Nyaw M.K. (2007) "The effect of trust on International joint venture performance in China" Journal of International Management, 13, 430-448.

Ngammaneeudom, C. (2012, June 20). The Journey: Thailand SME Promotion Structure retrieved from www.msmenewsnetwork.com

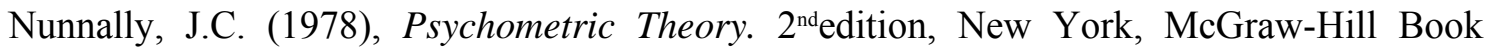
Company

Park, B. (2010). What matters to managerial knowledge acquisition in international joint ventures? High knowledge acquirers versus low knowledge acquirers, Asia Pacific Journal of Management 27(1):55-79. doi:10.1007/s10490-008-9111-6. 
The Consequence of Partner Relationship Quality to Predict the Successful Performance of Small and Medium

Enterprises (SMEs) International Joint Ventures (IJVs) in Thailand Industrial Sectors

Pearch, R.J. (2001). Looking Inside The Joint Venture to Help Understand The Link Between Inter-Parent Cooperation and Performance. Journal of Management Studies. June. 38:4,p. 558-582.

Public Relations Department (2011, March 18). SMEs to Receive a Major Boost to Help Develop Thailand's Creative Economy retrieved from http://thailand.prd.go.th

Robson, M.J., Leonidou, L.C., \& Katsikeas, C.S. (2002). Factors Influencing International Joint Venture Performance: Theoretical Perspectives, Assessment and Future Directions. Management International Review, 42(4), 385.

Schuler, R., \&Tarique, I., (2005). International Joint Venture System Complexity and Human Resources Management. In I.Bjorkman and Gunter Stahl (eds.). Handbook of Research in IHRM. London: Edward Elgar Publishing.

Schuler, R., \& Tarique, I., (2005). International Joint Venture System Complexity and HumanResources Management. In I. Bjorkman and Gunter Stahl (eds.). Handbook of Research in IHRM. London: Edward Elgar Publishing.

Sharmeas, D., Katsikeas, C.S., \& Schlegelmilch, B.B. (2002).Drives of Commitment and its impact on Performance in cross-cultural buyer-seller relationship: The importer's perspective. Journal of International Business Studies, Vol.33, No.4,p.757-783

Sin L.Y.M., Tse A.C.B., Chan H., Heung V.C.S. \&Yim F.H.K. (2006) "The effects of relationship marketing orientation on business performance in hotel industry" Journal of Hospitality \& Tourism Research”, Vol.30:470.

Sin L.Y.M., Tse. A.C.B., Yau O.H.M., Chow R.P.M., Lee J.S.Y. (2005) "Market Orientation, Relationship Marketing Orientation, and business performance: The moderating effects of economic ideology and industry type" Journal of International Marketing” Vol.13, No.1,pp. 36-57.

Small and Medium Enterprise Development Bank of Thailand: SME Bank, (Annual Report, 2008) retrieved from http://www.smebank.co.th

Thuy, L. X. \& Quang, T. (2005). Relational Capital and Performance of International Joint Ventures in Vietnam. Asia pacific Business Review,11(3), 389-410.

Tiessen, J.H., \& Linton, J.D. (2000). The JV dilemma: cooperating and completing in Joint Venture. Canadian Journal of Administrative Science. Vol.17, No.3 (Sep 2000)

Wadeecharoen, W., \& Nik, Mat, N. K. (2008). The Significance of Relationship Marketing Orientation on International Joint Venture (IJV) Performance in Thailand. The Journal of American Academy of Business, Cambridge, June 11-14.

Wadeecharoen, W., \& Nik, Mat, N. K. (2009). The Mediating Effects of Relationship Marketing Orientation (RMO) on the Antecedents of International Joint Venture (IJV) Performance in Thailand. Proceeding of Australian \& NewZealand Marketing Conference (ANZMAC): Sustainable Management \&Marketing Conference,30 Nov-2 Dec 2009. 
Wadeecharoen, W., \& Nik, Mat, N. K. (2010a). The Direct and Indirect Determinants of SME Performence in IJV Sector. The SMEs in a Global Economy Conferences, Sponsored by Faculty of Business Management, (UiTM),Malaysia, Japan (University of Senshu) and China (Beijing Information, Science and Technology University), 15-17 Oct 2010.

Wadeecharoen, W., \& Nik, Mat, N. K. (2010b). The Applicable of Relational Marketing Orientation (RMO) to Explain IJV Performance in Thailand. Proceeding of International Conference on Business and Economics Research (ICBER 2010), Malaysia Conference, Sponsored and publication by Thomson ISI, 26-28 Nov 2010.

Wadeecharoen, W., \& Nik, Mat, N. K. (2011). The Significance Role of Relational Factors and the Intervening Effect of Relationship Marketing Orientation (RMO)toward inter-partner relationship: CaseStudy of International Joint Venture (IJV) Performance in Thailand. Proceeding of National Conference on Research through Sustainable Development, Benjamit National Conference, 31 May, 2011 Thonburi University, BKK Thailand.

Wadeecharoen, W., Kanjanavanikul, A., Lertnaisat, R., \& Teekasap, S. (2012:a). A Contribution of Small and Medium Enterprise (SMEs) International Joint Venture (IJVs) to Sustain Thailand Economic Development. Proceeding of International Conference on Business and Industrial Research, Thai-NichiIntitute of Technology, Bangkok, Thailand,May 17-18, 2012

Wadeecharoen, W., Kanjanavanikul, A., Pattana, W., \& Teekasap, S. (2012:b) Suatainable of Small and Medium Business Enterprise (SMEs) in Asean Economic Community (AEC) Development and the Competitive Advantage of International Joint Venture (IJV) in Thailand ThaiTIMA: Annual Conference for Managing Technology \& Innovation towards Business Resiliency, July19-20, 2012

Wadeecharoen, W., Kanjanavanikul, A., Lertnaisat, R., \& Teekasap, S. (2012:c). An Examines of Thailand International Investment Position and the Role of Small and Medium Enterprises (SMEs) International Joint Venture (IJV) towards Thailand Economic Development. Proceeding of International Conference on Contemporary Business and Management ICOM 2012 Bangkok, December 10-12, 2012

Wilson J., Brennan, R. (2009) "Relational Factors in U.K.-Chinese International Joint Ventures" European Business Review, Vol.21, No.2,pp. 159-171

Yau, O., McFetridge, P., Chow, R., Lee, J., Sin, L., Tse, A., (2000). Is Relationship Marketing for Everyone, European Journal of Marketing, 34, (9/10)

Yeheskel, O., Newburry, W. \& Zeira Y. (2004). Significant differences in the pre- and post- incorporation stages of equity international joint ventures and international acquisitions and their impacts on effectiveness, International Business Review 13, 613-636.

Yeheskel, O., Newburry, W. \& Zeira Y. (2004). Significant differences in the pre- and postincorporation stages of equity international joint ventures and international acquisitions and their impacts on effectiveness, International Business Review 13, 
The Consequence of Partner Relationship Quality to Predict the Successful Performance of Small and Medium Enterprises (SMEs) International Joint Ventures (IJVs) in Thailand Industrial Sectors

613-636.

Zyl, H.J.C.V., \& Helm, M. (2007).Exploring a conceptual model, based on the combined effects of entrepreneurial leadership, market orientation and relationship marketing orientation on South Africa's small tourism business performance. Journal of Business Management. Vol. 38(2) 


\section{Appendix A. Measures}

\section{A: Market Orientation (MO)}

Scale: $1=$ Very Unlikely, $2=$ Unlikely, $3=$ Quite Unlikely, $4=$ Equitable, $5=$ Quite Likely, $6=$ Likely, $7=$ Very Likely

1. Our IJV objectives are driven primarily by partner satisfaction

2. Both IJV partners constantly monitor our level of commitment and orientation to serving partner satisfaction.

3. Our IJV measure both partners satisfaction systematically and frequently.

4. Our IJV regularly share information within our partners concerning competitor's strategies.

5. Our IJV freely communicating information about our successful and unsuccessful of IJV partner experiences across all business functions.

6. Exchanges of information between IJV partners take place frequently, informally, and openly.

7. All of our IJV business functions (e.g. marketing/sales, manufacturing, R\&D, finance/accounting etc.) are integrated in serving the needs of our target markets.

8. All of our IJV managers understand how everyone in our business can contribute to creating partner value.

9. Before foreign and local partners share resources for inter-functional IJV operation.

10. Our IJV strategies for competitive advantage are based on our understanding of partner's needs.

11. Both IJV partners rapidly respond to competitive actions that threaten us.

12. Our IJV target new market where we have an opportunity for competitive advantage.

\section{B: Relationship Marketing Orientation (RMO)}

Scale: $1=$ Very Unlikely, $2=$ Unlikely, $3=$ Quite Unlikely, $4=$ Equitable, $5=$ Quite Likely, $6=$ Likely, $7=$ Very Likely

1. Bonding

- My enterprise achievement builds on our reliance on each other

- We keep in touch constantly

- We work in close co-operation

\section{Empathy}

- We know how each other feels

- We always see things from each other's view

- We care about each other's feelings

\section{Reciprocity}

- If anyone helps my company to solve difficulties, I am responsible to reply his/her kindness

- We always regard "never forget a good turn" as our business motto

- We keep our promise

4. Trust

- He/she is trustworthy on important things

- I trust each other

- We trust each other

\section{C: SME IJV Performance}

Scale: $\quad 1=$ Far Less than expected, $2=$ Less than expected, $3=$ Less than expected, $4=$ Equitable, $5=$ Quite than expected, $6=$ More expected, $7=$ Far more than expected

1. Our IJV has show less growth potential than we expected

2. Overall we consider our IJV to be successful

3. The IJV output has achieved good Thai market penetration

4. The IJV overall performance is high

5. Return on Investment (ROI) is high

6. Both IJV partner's goals (both foreign and Thai parents) are achieved 